\title{
Optimalisasi Model ARCS Dalam Pembelajaran Saintifik Untuk Meningkatkan Motivasi Belajar Peserta Didik Pada Peminatan Mata Pelajaran Geografi Di Kelas Matematika Ilmu Alam
}

\author{
Mekka Madaina Jamil ${ }^{1}$ \\ ${ }^{1}$ Student of Geographic Education Sekolah Pascasarjana Univesitas Pendidikan Indonesia \\ Coressponding Author. E-mail: \\ ${ }^{1}$ mom_days@yahoo.co.id \\ Received: 10 Juli 2018 \\ Accepted: 25 Oktober 2018 Online Published: 13 Januari 2019
}

\begin{abstract}
Abstrak
Pembelajaran merupakan suatu sistem yang terdiri dari beberapa komponen yang saling berinteraksi salah satunya strategi pembelajaran. Motivasi merupakan salah satu faktor yang turut serta menentukan hasil belajar dan tercapainya tujuan pembelajaran. Motivasi belajar seringkali menjadi aspek yang diabaikan dari strategi pembelajaran. Pembelajaran saintifik merupakan pembelajaran yang direkomendasikan untuk digunakan di setiap mata pelajaran dan pada semua jenjang. Tujuan penulisan makalah ini adalah; Menjelaskan optimalisasi model pembelajaran ARCS sebagai upaya meningkatkan motivasi belajar peserta didik khususnya dalam pembelajaran saintifik pada peminatan mata pelajaran geografi di kelas Matematika Ilmu Alam. Metode yang digunakan adalah studi literatur. Kesimpulan penulisan makalah ini adalah Model ARCS dapat menjadi salah satu alternatif untuk meningkatkan motivasi belajar peserta didik baik digunakan sebagai model pembelajaran dan alat ukur tingkat motivasi belajar peserta didik. Mempertahankan dan meningkatkan motivasi belajar peserta didik menjadi hal yang sangat penting dalam mendukung tercapainya tujuan pembelajaran..
\end{abstract}

Kata Kunci: Model ARCS, Pembelajaran Saintifik, Motivasi Belajar.

\section{Optimization of the ARCS Model in Scientific Learning to Improve Learning Motivation of Students in Specialization in Geography in Mathematics in Natural Sciences}

\begin{abstract}
Learning is a system that consists of several components that interact with one of them learning strategies. Motivation is one of the factors that contribute to determining learning outcomes and achieving learning goals. Learning motivation is often a neglected aspect of the learning strategy. Scientific learning is a recomended learning for two subjects and at all levels. The purpose of this plot of writing is; Explaining the optimization of the ARCS learning model as an effort to improve the learning motivation of students especially in scientific learning there is specialization in geography subjects at Science and Math class. The method used is literature study. Conclusion of this paper is that the ARCS model can be an alternative to improve the learning motivation of students both used as learning models and learners motivation levels. Maintaining and increasing students learning motivation is very important in supporting the achievement of learning goals.
\end{abstract}

Keywords: ARCS Model, Scientific Learning, Learning Motivation 


\section{PENDAHULUAN}

Pembelajaran merupakan suatu sistem yang terdiri dari beberapa komponen yang saling berinteraksi. Komponen pembelajaran tersebut di antaranya adalah guru, peserta didik, model dan metode, media, materi, pendekatan dalam konsep pembelajaran dan alat evaluasi. Antar komponen saling mempengaruhi secara fungsional bagi ketercapaian tujuan pembelajaran. Peserta didik merupakan pelaksana dari proses pembelajaran memiliki beberapa faktor pendukung bagi ketercapaian tujuan pembelajaran. Prestasi belajar peserta didik merupakan objek yang terukur pada tingkat keberhasilan tujuan pembelajaran melalui nilai baku yang tercapai.

Selain faktor pendukung bagi ketercapaian tujuan pembelajaran terdapat beberapa faktor yang menjadi hambatan peserta didik dalam pembelajaran. Pada faktor yang turut serta menentukan hasil belajar, baik yang berasal dari peserta didik maupun yang berasal dari komponen pembelajaran. Faktor yang berasal dari peserta didik seperti motivasi, daya intelegensi, dan konsentrasi. Dari ketiga faktor tersebut motivasi seringkali menjadi aspek yang paling diabaikan dari strategi pembelajaran. Menurut Slavin (1991: 203) bahwa 'motivasi merupakan salah satu prasyarat yang paling penting dalam belajar. Bila tidak ada motivasi, proses belajar tidak akan terjadi. Motivasi dapat mempengaruhi proses dan hasil belajar'.

Dalam dunia pendidikan motivasi belajar merupakan hal penting yang dapat menjamin kelangsungan proses belajar mengajar. Sebagaimana dikemukakan Rusyan (1989: 23) bahwa: Motivasi merupakan faktor yang sangat penting di dalam belajar. Pentingnya sebuah materi pembelajaran menjadi target tersendiri bagi pengajar untuk memberi pemahaman pada peserta didiknya. Apabila peserta didik memiliki motivasi belajar yang baik maka proses pembelajaran diharapkan dapat berlangsung dengan baik.

Belajar merupakan suatu proses interaksi antara peserta didik dengan lingkungannya, yang menyebabkan terjadinya perubahan pada dirinya. Kegiatan belajar dipengaruhi oleh suatu kondisi, baik intern maupun ekstern. Pengaruh intern yang sangat kuat dalam mencapai tujuan belajar adalah minat. Dengan minat yang kuat untuk belajar, maka akan dapat mencapai tujuan belajar dengan mudah. Dalam hal ini minat termasuk ke dalam unsur motivasi pada Model Motivasi ARCS (Keller, 1987:7).
ARCS adalah model pembelajaran dengan desain instruksional yang dikembangkan oleh Keller dan berfokus pada motivasi. Salah satu model pembelajaran inovatif yang mampu membangkitkan motivasi belajar peserta didik. Model ARCS merupakan suatu pendekatan pemecahan masalah untuk merancang aspek motivasi serta lingkungan belajar dalam mendorong dan mempertahankan motivasi peserta didik untuk belajar. Model pembelajaran ARCS akan memberikan kesempatan kepada peserta didik untuk menggunakan pengetahuan awalnya dalam mengkontruksikan pengetahunnya sendiri sehingga peserta didik memahami konsep-konsep yang sedang dipelajari dan pada akhirnya dapat digunakan untuk memecahkan permasalahan yang diberikan guru. Pada dasarnya model ini merupakan suatu pengembangan model motivasi dari teori motivasi kontemporer. Teori motivasi kontemporer tersebut terdiri dari Teori Kebutuhan Menurut McClelland, Teori Evaluasi Kognitif, Teori Penentuan Tujuan, Teori Model Motivasi ARCS, dan Teori Model Motivasi ARIAS.

Model motivasi ARCS ini ditemukan dan dipublikasikan Keller (1987: 2-9). ARCS merupakan singkatan dari minat/perhatian (Attention), relevansi (Relevance), percaya diri/yakin (Confidence), kepuasan/bangga (Satisfaction) dan menjadi empat kategori yang mewakili bermacam karakteristik motivasi yang ada dalam setiap individu. Model dasar untuk desain Motivasi Pembelajaran ARCS merupakan analisis permasalahan motivasi peserta didik berdasarkan pada mata pelajaran, yang di dalamnya terdapat empat kategori yang menjadi strategi dalam desain motivasi ARCS, yaitu: (1) Minat/Perhatian peserta didik terhadap mata pelajaran dalam membangun rasa ingin tahu dan perhatian yang berkelanjutan, (2) Relevan/Hubungan untuk menghubungkan Mata Pelajaran dengan motif dan kepentingan yang dibutuhkan peserta didik dari pembelajaran tersebut, (3) Harapan peserta didik dari mata pelajaran tersebut dalam membangun kepercayaan diri dengan motivasi untuk kesuksesan, (4) Kepuasan peserta didik dari proses pembelajaran pada mata pelajaran tersebut untuk mengelola penguatan intrinsik dan ekstrinsik.

Menurut Scheinder (2007: 23), model ini sangat penting untuk pendidikan terutama pendidikan jarak jauh, ataupun peninjauan motivasi peserta didik dalam proses pembelajaran, karena motivasi merupakan faktor kunci yang menentukan apakah pelajar menyelesaikan pelatihan mereka. Model ini berfokus pada motivasi ekstrinsik dan 
dikembangkan untuk mendorong timbulnya motivasi intrinsik dalam diri siswa. Model ARCS juga digunakan sebagai panduan desain untuk mengembangkan strategi motivasi yang efektif (Song \& Keller, 2001).

Terdapat dua pilihan kategori penelitian pada Model ARCS, pertama Model ARCS sebagai seperangkat kategori yang memiliki komponen motivasi. Kategori ini adalah hasil sintesis dari penelitian tentang motivasi manusia yang di dalamnya terdapat modifikasi subkategori model motivasi ARCS, penelitian pada kategori ini terfokus pada peserta didik dengan seperangkat alat pengukuran tertentu hingga menghasilkan tingkat motivasi belajar peserta didik. Kedua, Model ARCS sebagai proses dari desain sistematis yang membantu dalam menciptkan perangkat tambahan motivasi yang sesuai untuk diberikan kepada peserta didik yang di dalamnya terdapat identifikasi berbagai elemen motivasi siswa juga proses desain yang membantu untuk profil/karakteristik motivasi siswa dalam lingkungan belajar. Penelitian pada kategori ini melibatkan peserta didik dan guru dengan metode dan seperangkat alat ukur tertentu dari model ARCS hingga menghasilkan rancangan taktik motivasi yang sesuai untuk peserta didik berdasarkan tingkat motivasi belajar peserta didik.

Metode pembelaran yang dapat diterapkan dalam model ARCS ini adalah seluruh metode pembelajaran yang interaktif. Diantara metode yang interaktif dan dianggap dapat meningkatkan motivasi belajar peserta didik adalah melalui metode pemecahan masalah dan diskusi. Karena pada dasarnya tujuan akhir pembelajaran adalah menghasilkan peserta didik yang memiliki pengetahuan dan keterampilan dalam memecahkan masalah yang dihadapi kelak di masyarakat. Adapun metode diskusi yang diterapkan dalam hal ini menjadi bagian metode pembelajaran yang interaktif dan melatih kemandirian peserta didik. Sehingga melalui kedua metode tersebut peserta didik menjalankan proses pembelajaran yang interaktf, mandiri dan mampu menemukan pemecahan masalah yang efektif dan efisien.

Dalam pembelajaran saintifik mata pelajaran Geografi merupakan salah satu mata pelajaran yang wajib diikuti oleh peserta didik khususnya pada kelas Ilmu-ilmu Sosial dan menjadi mata pelajaran peminatan bagi kelas Matematika Ilmu Alam yang berminat mempelajari dan mendalaminya. Dalam hal ini pembelajaran saintifik merupakan pembelajaran yang tengah diterapkan dalam dunia pendidikan di Indonesia. Sebagaimana dikemukakan Yani dan Ruhimat (2018: 3) bahwa di Indonesia pembelajaran saintifik direkomendasikan untuk digunakan di setiap mata pelajaran dan pada semua jenjang pendidikan melalui Peraturan Menteri Pendidikan dan Kebudayaan Nomor 22 Tahun 2016 tentang Standar Proses Pendidikan Dasar dan Menengah.

Menurut Yani dan Ruhimat (2018: 36) Pembelajaran saintifik yang diusung oleh kurikulum 2013 adalah pembelajaran yang berorientasi pada peserta didik (student center) dan banyak memiliki "peluang" untuk mengembangkan karakter peserta didik. Sehingga pembelajaran saintifik dapat menjadi salah satu solusi agar pembelajaran dapat mencapai dua target dampak pembelajaran dan dampak pengiringnya secara bersama-sama dan kontinue. Rumpun pembelajaran saintifik diantaranya; inkuiri dan diskoveri, pembelajaran berbasis masalah, pembelajaran berbasis projek, pembelajaran berbasis kasus, dan pembelajaran melalui metode field trip (Yani dan Ruhimat, 2018: 65). Strategi dalam pembelajaran saintifik terdiri dari beberapa tahap, yakni; tahap mengamati, tahap menanya, tahap mengumpulkan informasi / eksperimen, tahap mengasosiasi, dan tahap mengkomunikasikan (Yani dan Ruhimat, 2018: 99). Kajian ini berorientasi pada tujuan yang hendak dicapai, yakni: Menjelaskan optimalisasi model pembelajaran ARCS sebagai upaya untuk meningkatkan motivasi belajar peserta didik dalam pembelajaran saintifik pada peminatan mata pelajaran geografi di kelas Matematika Ilmu Alam.

\section{METODE}

Kajian ini menggunakan studi literatur untuk mengungkapkan teori, konsep, penelitian terdahulu, dan pendapat para ahli sebagai landasan untuk menjelaskan optimalisasi model pembelajaran ARCS dan motivasi belajar peserta didik sebagai upaya meningkatkan motivasi belajar peserta didik dalam pembelajaran saintifik pada peminatan mata pelajaran geografi.

\section{HASIL DAN PEMBAHASAN}

Model ARCS (Attention, Relevance, Confidence, Satisfaction), Model motivasi ini ditemukan dan dipublikasikan oleh John M Keller pada tahun 1987. Model motivasi ini pada akhirnya dikembangkan untuk mendorong timbulnya motivasi intrinsik dalam diri siswa melalui model pembelajaran ARCS. Model motivasi ini memiliki empat kategori yang mewakili bermacam 
karakteristik motivasi yang ada dalam setiap individu, yaitu :

a. Attention (minat/perhatian)

Attention yaitu berhubungan dengan minat/perhatian siswa. Menurut Woodruff seperti dikutip Callahan (1966: 23) bahwa sesungguhnya belajar tidak terjadi tanpa ada minat/perhatian. Keller seperti dikutip Reigeluth (1987: 383-430) menyatakan bahwa: Dalam kegiatan pembelajaran minat/perhatian tidak hanya harus dibangkitkan melainkan juga harus dipelihara selama kegiatan pembelajaran berlangsung. Pengajar harus memperhatikan berbagai bentuk dan memfokuskan pada minat/perhatian dalam kegiatan pembelajaran.

Sebagaimana Herndon (1987: 11-14) menunjukkan bahwa:

"Adanya minat/perhatian siswa terhadap tugas yang diberikan dapat mendorong siswa melanjutkan tugasnya. Siswa akan kembali mengerjakan sesuatu yang menarik sesuai dengan minat/perhatian mereka. Membangkitkan dan memelihara minat/perhatian merupakan usaha menumbuhkan keingintahuan siswa yang diperlukan dalam kegiatan pembelajaran. Minat/perhatian merupakan alat yang sangat berguna dalam usaha mempengaruhi hasil belajar siswa".

b. Relevance (relevansi)

Relevance yaitu berhubungan dengan kehidupan siswa baik berupa pengalaman sekarang atau yang telah dimiliki maupun yang berhubungan dengan kebutuhan karir sekarang atau yang akan datang. Keller (1987: 2-9) mengemukakan bahwa peserta didik merasa kegiatan pembelajaran yang mereka ikuti memiliki nilai, bermanfaat dan berguna bagi kehidupan mereka. Peserta didik akan terdorong mempelajari sesuatu kalau apa yang akan di pelajari ada relevansinya dengan kehidupan mereka, dan memiliki tujuan yang jelas.

Gagne dan Driscoll (1988: 140) menyatakan bahwa:

"Sesuatu yang memiliki arah tujuan, dan sasaran yang jelas serta ada manfaat dan relevan dengan kehidupan akan mendorong individu untuk mencapai tujuan tersebut. Maka dengan tujuan yang jelas mereka akan mengetahui kemampuan apa yang akan di miliki dan pengalaman apa yang di dapat. Mereka juga akan mengetahui kesenjangan antara kemampuan yang telah dimiliki dengan kemampuan baru itu sehinga kesenjangan tadi dapat dikurangi atau bahkan dihilangkan sama sekali. Dalam kegiatan pembelajaran, para pengajar perlu memperhatikan unsur relevansi ini."

Menurut DeCecco (1968: 162) beberapa cara yang dapat digunakan untuk meningkatkan relevansi dalam pembelajaran adalah: mengemukakan tujuan sasaran yang akan di capai. Tujuan yang jelas akan memberikan harapan yang jelas (konkrit) pada siswa dan mendorong mereka untuk mencapai tujuan tersebut.

Semiawan (1991) menyatakan bahwa:

"Hal ini akan mempengaruhi hasil belajar mereka. (a) Mengemukakan manfaat pelajaran bagi kehidupan siswa baik untuk masa sekarang dan/atau membagi aktivitas dimasa mendatang. (b) Menggunakan bahasa yang jelas atau contoh-contoh yang ada hubungannya dengan pengalaman nyata atau nilai-nilai yang dimiliki siswa, pengalaman nyata atau langsung dialami siswa dapat menjembataninya ke hal-hal baru, pengalaman selain memberi keasyikan bagi siswa juga diperlukan secara esensial sebagai jembatan mengarah kepada titik tolak yang sama dalam melibatkan siswa secara mental, emosional, sosial dan fisik, sekaligus merupakan usaha melihat lingkup permasalahan yang sedang dibicarakan. (c) Menggunakan berbagai alternatif strategi dan media pembelajaran yang cocok untuk pencapaian tujuan. Dengan demikian dimungkinkan menggunakan bermacammacam strategi dan/atau media pembelajaran pada setiap kegiatan pembelajaran."

c. Confidence (percaya diri/yakin)

Menurut Keller (1987: 2-9) Confidence berhubungan dengan sikap percaya, yakin akan berhasil atau yang berhubungan dengan harapan untuk berhasil. bahwa:

Gagne dan Driscoll (1988: 70) menyatakan

"Seseorang yang memiliki sikap percaya diri yang tinggi cenderung akan berhasil bagaimanapun kemampuan yang ia miliki. Sikap dimana seseorang merasa yakin, percaya dapat berhasil mencapai sesuatu akan mempengaruhi mereka bertingkah laku untuk mencapai keberhasilan tersebut. Sikap ini mempengaruhi kinerja aktual seseorang, sehingga perbedaan dalam sikap ini menimbulkan perbedaan dalam kinerja." 
d.Satisfaction (kepuasan/bangga)

Satisfaction yaitu yang berhubungan dengan rasa bangga, puas atas hasil yang dicapai. Menurut Gagne dan Driscoll (1988: 70) dalam teori belajar satisfaction adalah reinforcement (penguatan). Peserta didik yang telah berhasil mengerjakan atau mencapai sesuatu merasa bangga/puas atas keberhasilan tersebut. Keberhasilan dan kebanggan itu menjadi penguat bagi siswa tersebut untuk mencapai keberhasilan berikutnya. Menurut Hilgard dan Bower (1975: 561) Reinforcement atau penguatan yang dapat memberikan rasa bangga dan puas pada siswa adalah penting dan perlu dalam kegiatan pembelajaran.

bahwa:

Menurut Keller dan Kopp (1987: 2-9)

"Berdasarkan teori kebanggaan, rasa puas dapat timbul dari dalam diri individu sendiri yang disebut kebanggaan intrinsik dimana individu merasa puas dan bangga telah berhasil mengerjakan, mencapai, atau mendapat sesuatu. Kebanggaan dan rasa puas ini juga dapat timbul karena pengaruh dari luar individu, yaitu dari orang lain atau lingkungan yang disebut kebanggaan ekstrinsik. Seseorang merasa bangga dan puas karena apa yang dikerjakan dan dihasilkan mendapat penghargaan baik bersifat verbal maupun non verbal dari orang lain atau lingkungan."

Memberikan penghargaan (reward) menurut Thorndike seperti dikutip oleh Gagne dan Briggs (1979: 8) merupakan suatu penguatan (reinforcement) dalam kegiatan pembelajaran. Dengan demikian, memberikan penghargaan merupakan salah satu cara yang dapat digunakan untuk mempengaruhi hasil belajar siswa. Untuk itu, rasa bangga dan puas perlu ditanamkan dan dijaga dalam diri siswa.
Empat komponen di atas dapat mengungkap tingkat motivasi ekstrinsik siswa pada mata pelajaran Geografi setelah diukur menggunakan survey motivasi yang dirancang berdasarkan model motivasi ARCS, yaitu IMMS (Instructional Materials Motivation Survey). Dalam aplikasi pengukuran motivasi peserta didik dapat dilakukan dengan menggunakan instrumen baku ARCS yaitu IMMS (Instructional Materials Motivation Survey). IMMS merupakan alat ukur berupa kuisioner yang digunakan untuk mengukur dan mengetahui tingkat motivasi peserta didik terhadap suatu materi pembelajaran tertentu. Menurut Keller (1987: 3-5) model ini memiliki kategori tingkat motivasi yang didasarkan pada kondisi peserta didik. Kondisi motivasi belajar merupakan suatu kondisi yang membutuhkan stimulasi eksternal agar dapat menumbuhkan kondisi internal pemelajar.

Model ARCS dapat digunakan dan diterapkan oleh guru di sekolah sebagai alternatif ataupun salah satu model pembelajaran yang inofativ baik pada pembelajaran Geografi ataupun disesuaikan dengan mata pelajaran lainnya. Guru menjadi fasilitator utama yang berperan penting dalam optimalisasi motivasi belajar peserta didik. Guru dapat melakukan pengukuran tingkat motivasi belajar peserta didik secara mandiri dan dapat segera membantu meningkatkan kembali motivasi belajar dengan memperbaiki dan menerapkan kembali model ARCS menggunakan metode yang lebih bervariasi dan penambahan sarana-sarana pembelajaran lainnya untuk mempertahankan tingkat motivasi belajar peserta didik yang tinggi dan berdampak baik pada hasil belajar.

Adapun langkah-langkah yang digunakan dalam model pembelajaran ARCS adalah pada tabel 1. :

Tabel 1. Langkah-langkeah model pembelajaran ARCS

\begin{tabular}{cc}
\hline \multicolumn{2}{c}{ Peristiwa } \\
Pembelajaran ARCS
\end{tabular}




\begin{tabular}{|c|c|}
\hline $\begin{array}{l}\text { 2) Menyampaikan tujuan } \\
\text { dan manfaat } \\
\text { pembelajaran }(\mathrm{R})\end{array}$ & $\begin{array}{l}\text { Guru mendeskripsikan tujuan dan manfaat pembelajaran, } \\
\text { serta dapat mengetahui hubungan atau keterkaitan antara materi } \\
\text { pembelajaran yang disajikan dengan pengalaman belajar siswa } \\
\text { tersebut }\end{array}$ \\
\hline $\begin{array}{l}\text { 3) Menyampaikan materi } \\
\text { pelajaran }(\mathrm{R})\end{array}$ & $\begin{array}{l}\text { Guru menyampaikan materi pembelajaran secara jelas dan } \\
\text { terperinci . penyampaian materi ini dilakukan dengan cara yang } \\
\text { dapat menarik sehingga dapat menumbuhkan atau menjaga } \\
\text { perhatian siswa. } \\
\text { Guru dapat menyampaikan materi melalui proses interaktif, } \\
\text { seperti menggunakan pendekatan problem solving, belajar } \\
\text { kooperatif, atau diskusi kelas dan lain sebagainya. }\end{array}$ \\
\hline $\begin{array}{l}\text { 4) Menggunakan contoh- } \\
\text { contoh yang konkrit } \\
(\text { A dan } \mathrm{R})\end{array}$ & $\begin{array}{l}\text { Guru memberikan contoh-contoh yang nyata serta ada } \\
\text { hubungannya dengan kehidupan sehari-hari siswa sehingga siswa } \\
\text { merasa tertarik untuk mengikuti pembelajaran. }\end{array}$ \\
\hline $\begin{array}{l}\text { Memberi bimbingan } \\
\text { belajar }(\mathrm{R})\end{array}$ & $\begin{array}{l}\text { Guru memotivasi dan mengarahkan siswa agar lebih mudah } \\
\text { dalam memahami materi pembelajaran yang disajikan. } \\
\text { Bimbingan yang diberikan bukan memberikan jawaban } \\
\text { kepada siswa tetapi bantuan yang diberikan melalui pertanyaan- } \\
\text { pertanyaan yang terarah agar siswa dapat menemukan jawabannya } \\
\text { sendiri. }\end{array}$ \\
\hline
\end{tabular}

6) Memberi kesempatan

Guru memberikan kesempatan kepada siswa untuk bertanya, kepada siswa untuk berpartisipasi dalam pembelajaran (C dan S) menanggapi, ataupun mengerjakan soal mengenai materi pelajaran.

7) Memberi umpan balik (S)

Guru memberikan suatu umpan balik yang tentunya dapat merangsang pola berfikir siswa. Setelah umpan balik ini siswa secara aktif feedback dari guru tersebut.

Umpan balik positif dapat menguatkanrasa percaya diri siswa karena menghasilkan pemikiran yang benar

8) Menyimpulkan setiap materi yang telah disampaikan di akhir pembelajaran (S)
Pada langkah ini guru menyimpulkan materi pembelajaran yang baru saja disajikan dengan jelas dan terperinci. Langkah ini dapat dilakukan dengan berbagai macam cara diantaranya memberikan kesempatan kepada seluruh siswa untuk membuat kesimpulan tentang materi yang baru mereka pelajari dengan menggunakan bahasa mereka sendiri. Secara tidak langsung langkah ini dapat menciptakan rasa puas dalam diri siswa. Serta memberikan pengalaman untuk menerapkan materi yang dipelajari dalam bentuk latihan dan tugas-tugas.

Sumber (Hamoraon, 2010: 7)

Pembelajaran saintifik merupakan suatu pendekatan yang dapat dipadankan dengan suatu proses ilmiah, Karena itu Kurikulum 2013 mengamanatkan esensi pendekatan saintifik dalam pembelajaran. Menurut Muhajir dan Khatimah (2013: 47). Pendekatan saintifik diyakini sebagai titian emas perkembangan dan pengembangan sikap, keterampilan, dan pengetahua peserta didik. Hal ini sejalan dengan pendapat Savage \& Amstrong (1996: 11) bahwa "for each broad social studies purpose there are three emphases that need to be identify: knowledge, skill, and values". Disisi lain tujuan 
pendidikan tiada lain adalah mengembangkan jasmani, mensucikan rohani dan menumbuhkan akal (Zamroni, 2002: 186), sehingga keberhasilan suatu pendidikan tidak hanya diukur dari pencapaian aspek pengetahuan saja, tetapi lebih penting adalah dari aspek sikap dan perilaku. Oleh karena itu, dibutuhkan system penilaian yang mengakomodasi ketiga ranah tersebut, sehingga menjadi hasil belajar yang bermakna bagi siswa.

Pendekatan saintifik atau pendekatan ilmiah dikembangkan dengan tujuan agar pembelajaran berjalan lebih efektif karena mampu mewadahi dan menyentuh secara terpadu dimensi emosi, fisik, dan akademik siswa di dalam kelas atau di lingkungan sekolah. Pembelajaran yang dilakukan dengan menggunakan pendekatan saintifik kegiatan belajar berpusat pada siswa, siswa aktif dan kreatif selama kegiatan pembelajaran berlangsung. Menurut Kosasih (2014: 72), pendekatan saintifik merupakan pendekatan di dalam kegiatan pembelajaran yang mengutamakan kreativitas dan temuan-temuan siswa. Pengalaman belajar yang mereka peroleh tidak bersifat indoktrinisasi, hafalan dan sejenisnya. Pengalaman belajar, baik itu yang berupa pengetahuan, keterampilan, dan sikap mereka peroleh berdasarkan kesadaran dan kepentingan mereka sendiri.

Agar pembelajaran dapat mencapai dua target beriringan antara dampak yang bersifat langsung (Instructional effect) dan dampak pengiringnya (nurturant effect), salah satu solusinya menurut Yani dan Ruhimat (2018: 36) adalah melalui pembelajaran yang berorientasi kepada peserta didik. (student center). Pembelajaran yang berorientasi pada aktivitas memiliki peluang yang lebih banyak untuk mengembangkan karakter peserta didik dibandingkan dengan pembelajaran yang berorientasi pada aktifitas guru. Seperti kegiatan diskusi kelompok akan lebih banyak memiliki dampak pengiringnya untuk mengembangkan karakter toleransi dan tanggung jawab daripada kegiatan ceramah. Pembelajaran saintifik yang diusung oleh kurikulum 2013 adalah pembelajaran yang berorientasi pada peserta didik dan banyak memiliki "peluang" untuk mengembangkan karakter peserta didik.

Kurikulum 2013 menurut Kurniasih dan

Sani (2014: 32) merupakan rangkaian penyempurnaan terhadap kurikulum yang telah dirintis tahun 2004 yang berbasis kompetensi lalu diteruskan dengan kurikulum 2006. Perbedaan mendasar antara kurikulum 2013 dengan kurikulum sebelumnya adalah lebih meneguhkan pendekatan keilmuan untuk mendorong kreativitas peserta didik (Nuh, 2014: 4). Kurikulum 2013 merujuk pada teknik-teknik investigasi atas beberapa fenomena, memperoleh pengetahuan baru, atau mengoreksi dan memadukan pengetahuan sebelumnya. Menurut Fitri (2015: 2) untuk dapat disebut ilmiah, metode pencarian pada kurikulum 2013 merupakan pembelajaran berbasis pedekatan ilmiah (scientific approach) yang meliputi mengamati, menanya, mengumpulkan informasi, mengasosiasi, dan mengkomunikasikan. Dalam kurikulum 2013 tujuan pendidikan nasional dicerminkan dalam empat kompetensi, yaitu kompetensi inti mengenai sikap spiritual (KI 1), kompetensi mengenai sikap social (KI 2), kompetensi inti mengenai sikap pengetahuan (KI 3), dan kompetensi inti mengenai sikap keterampilan (KI 4) (Kemdikbud, 2013). Atas dasar tersebut, pendekatan ilmiah diyakini sebagai dasar perkembangan dan pengembangan sikap, keterampilan, dan pengetahuan siswa.

Sementara itu, Kemdikbud (2013) memberikan konsepsi tersendiri bahwa pendekatan ilmiah (scientific approach) dalam pembelajaran di dalamnya mencakup komponen: mengamati (observing), menanya (questioning), mencoba (experimenting), menalar (associating), serta membuat jejaring/mengkomunikasikan (networking). Komponen-komponen tersebut seyogyanya dapat dimunculkan dalam setiap praktik pembelajaran, baik dalam penyusunan tujuan di RPP maupun dalam kegiatan pembelajaran atau kegiatan inti khususnya (Supardan, 2014: 130).

Langkah pertama dalam proses pembelajaran saintifik adalah mengamati. Menurut Yani dan Ruhimat (2018: 99) Kegiatan mengamati memberikan kesempatan kepada peserta didik untuk mengoptimalkan kelima panca indera yang dimilikinya untuk menangkap dan memahami masalah. Peserta didik melihat, emngamati, dan menemukan masalah dari berbagai data dan informasi yang disajikan oleh guru, dari buku, pemutaran video (film), data sekunder, dan dari sumber belajar lainnya. Kegiatan ini akan efektif jika guru merancangnya dengan seksama, fokus, dan mengarahkan pola pikir peserta didik untuk menemukan masalah. Jika dilaksanakan tanpa arahan, maka peserta didik tidak akan berhasil menangkap masalah dari kegiatan mengamatinya.

Langkah kedua pada pembelajaran saintifik adalah menanya. Dalam Kamus Besar Bahasa Indonesia (KBBI), menanya (2008: 1628) sama maknanya dengan bertanya, yang berarti "mengajukan pertanyaan". Dalam pendekatan saintifik, pihak yang menanya adalah siswa. Pertanyaan yang muncul diharapkan terkait dengan 
objek yang telah diamatinya. Kegiatan belajar menanya dilakukan dengan cara mengajukan pertanyaan tentang informasi kyang tidak dipahami dari apa yang diamati (dimulai dari pertanyaan faktual sampai ke pertanyaan yang bersifat hipotetik). Kompetensi yang dikembangkan adalah mengembangkan kreativitas rasa ingin tahu, kemampuan merumuskan pertanyaan untuk membentuk pikiran kritis yang perlu untuk hidup cerdas dan belajar sepanjang hayat (Hosnan, 2014: 48).

Kegiatan ketiga adalah mengumpulkan Informasi/Eksperiman (mencoba). Mengumpulkan informasi/eksperimen merupakan tindak lanjut dari bertanya. Kegiatan pembelajarannya dengan menggali dan mengumpulkan informasi dari berbagai sumber melalui berbagai cara. Peserta didik dapat membaca buku yang lebih banyak, memperhatikan fenomena atau objek yang lebih teliti, atau bahkan melakukan eksperimen. Kompetensi yang dikembangkan dalam proses mengumpulkan informasi/eksperimen adalah mengembangkan sikap teliti, jujur, sopan, menghargai pendapat orang lain, kemampuan berkomunikasi, menerapkan kemampuan mengumpulkan informasi melalui berbagai cara yang dipelajari, mengembangkan kebiasaan belajar dan belajar sepanjang hayat. Dalam Permendikbud no. 103 tahun 2014, aktifitas mengumpulkan informasi dilakukan melalui mengeksplorasi, mencoba, membaca sumber lain selain buku teks, mengumpulkan data dari narasumber melalui angket, wawancara, dan memodifikasi/menambahi/mengembangkan.

Eksperimen/mencoba dapat di definisikan sebagai kegiatan terinci yang direncanakan untuk menghasilkan data untuk menjawab suatu masalah atau menguji suatu hipotesis (Hosnan, 2014: 58). Menurut Roestiyah (2001: 80), metode eksperimen adalah suatu cara mengajar, dimana siswa melakukan suatu percobaan tentang suatu hal, mengamati prosesnya serta menuliskan hasil percobaannya, kemudian hasil percobaan itu disampaikan ke kelas dan di evaluasi oleh guru. Pada saat yang sama, mereka belajar konten yang diperlukan dengan bimbingan guru. Sejalan dengan pendapat Rusman (2001: 105) bahwa "di era globalisasi sekarang ini diperlukan pengetahuan dan keanekaragaman keterampilan guru agar siswa mampu memberdayakan dirinya. Hal ini diperlukan agar siswa mampu menemukan, menafsirkan, menilai, dan menggunakan informasi serta melahirkan gagasan kreatif untuk menentukan sikap dalam pengambilan keputusan".
Kegiatan keempat adalah menalar / mengasosiasi (associating). Permendikbud No. 103 tahun 2014 menyatakan bahwa kegiatan dalam menalar/mengasosiasi dilakukan melalui kegiatan mengolah informasi yang sudah dikumpulkan, menganalisis data dalam bentuk membuat kategori, mengasosiasi atau menghubungkan fenomena/informasi yang terkait dalam rangka menemukan suatu pola dan menyimpulkan . Istilah "menalar" (associating) dalam kurikulum 2013 adalah untuk menggambarkan bahwa guru dan siswa merupakan pelaku aktif. Titik tekannya tentu dalam banyak hal dan situasi siswa harus lebih aktif dari guru. Penalaran adalah proses berpikir yang logis dan sistematis atau fakta-fakta empiris yang dapat diobservasi untuk memperoleh simpulan berupa pengetahuan. Pentingnya kegiatan berpikir ini diungkapkan Suriasumantri (2009: 19) bahwa berpikir adalah kegiatan mental yang menghasilkan pengetahuan.

Selain melatih berpikir kritis, pembelajaran saintifik juga akan merangsang untuk berperilaku jujur, disiplin, kreatif, dan mandiri (Machin, 2014: 31). Yani (2014: 122) mengungkapkan bahwa sikap jujur, disiplin, kreatif dan mandiri memang memiliki kedudukan yang penting dalam proses berpikir ilmiah. Jika peserta didik terbiasa melakukan asosiasi dan berpikir kritis maka memiliki peluang untuk berkembangnya sikap jujur, kreatif, dan mandiri.

Kegiatan kelima adalah mengkomunikasikan berarti menyampaikan hasil kegiatan sebelumnya kepada orang lain (Kosasih, 2014: 80). Pendekatan saintifik menuntut guru untuk memberikan kesempatan kepada peserta didik untuk mengkomunikasikan apa saja yang telah mereka pelajari. Kegiatan belajar mengkomunikasikan adalah menyampaikan hasil pengamatan, kesimpulan berdasarkan hasil analisis secara lisan, tertulis, atau media lainnya. Kompetemsi yang dikembangkan dalam tahapan mengkomunikasikan adalah mengembangkan sikap jujur, teliti, toleransi, kemampuan berpikir sistematis, mengungkapkan pendapat dengan singkat dan jelas, dan mengembangkan kemampuan berbahasa yang baik dan benar. Kegiatan ini bisa dilakukan bersamasama dalam satu kesatuan kelompok, atau bisa juga dengan dikerjakan sendiri setelah mendengarkan hasil kegiatan mengolah informasi.

Sementara menurut Slavin (1995: 2) menyatakan bahwa belajar secara berkelompok merupakan pembelajaran dimana siswa belajar dalam kelompok kecil yang bersifat heterogen dari segi kemampun akademik, saling membantu satu 
sama lain dalam mencapai tujuan bersama. Pembentukan kelompok yang heterogen dapat dilakukan dengan memperhatikan keanekaragaman gender, latar belakang social ekonomi dan etnik, serta kemampuan akademis (Lie, 2003: 40). Hasil tugas yang dikerjakan bersama dalam satu kelompok kemudian di presentasikan atau dilaporkan kepada guru dan teman sekelas.

\section{Motivasi Belajar}

Dalam kegiatan belajar, motivasi dapat dikatakan sebagai keseluruhan daya penggerak di dalam diri siswa yang menimbulkan kegiatan belajar, yang menjamin kelangsungan dari kegiatan belajar dan yang memberikan arah pada kegiatan belajar, sehingga tujuan yang dikehendaki oleh subjek belajar itu dapat tercapai. Hardjana (1994: 21) menyatakan bahwa: Dikatakan "keseluruhan" karena pada umumnya ada beberapa motif yang bersama-sama menggerakkan siswa untuk belajar. Motivasi belajar adalah dorongan atau stimulus yang datang dari dalam batin atau hati orang yang menggerakkan perilaku belajarnya untuk memenuhi kebutuhan atau mencapai sasaran yang ditujunya.

McCombs (1991: 137) menyatakan bahwa:

"Motivasi belajar adalah kemampuan internal yang terbentuk secara alami yang dapat ditingkatkan atau dipelihara melalui kegiatan yang memberikan dukungan, memberikan kesempatan untuk memilih kegiatan, memberikan tanggung jawab untuk mengontrol proses belajar dan memberikan tugas-tugas belajar yang bermanfaat dan sesuai dengan kebutuhan pribadi."

Untuk dapat terlaksananya suatu kegiatan, pertama-tama harus ada dorongan untuk melaksanakan kegiatan itu. Dengan kata lain, untuk dapat melakukan sesuatu harus ada motivasi. Begitu juga keadaannya dalam proses belajar atau pendidikan. Peserta didik harus mempunyai motivasi untuk mengikuti kegiatan belajar atau pendidikan yang sedang berlangsung. Menurut Rusyan (1989: 127) apabila mempunyai motivasi yang kuat, peserta didik akan menunjukkan minatnya, aktivitasnya, dan partisipasinya dalam mengikuti kegiatan belajar atau pendidikan yang sedang dilaksanakan. Menurut Slavin (1991: 203), motivasi merupakan salah satu prasyarat yang paling penting dalam belajar. Bila tidak ada motivasi, proses belajar tidak akan terjadi. Motivasi dapat mempengaruhi proses dan hasil belajar.

Adanya motivasi ini menunjukkan bahwa peserta didik menyadari bahwa kegiatan pembelajaran yang sedang diikutinya bermanfaat bagi dirinya karena sejalan dengan kebutuhannya. Motivasi ini sering juga disebut motivasi murni, motivasi yang sebenarnya timbul dari dalam diri anak sendiri. Jadi motivasi ini tidak dipengaruhi dari luar. Dalam hal ini ujian, hadiah atau sejenisnya tidak diperlukan karena tidak akan menyebabkan peserta didik bekerja atau belajar untuk mendapatkan ujian atau hadiah itu.

Secara umum terdapat dua peranan penting motivasi dalam belajar, pertama, motivasi merupakan daya penggerak psikis dalam diri siswa yang menimbulkan kegiatan belajar, menjamin kelangsungan belajar itu demi mencapai satu tujuan. Kedua, motivasi memegang peranan penting dalam memberikan gairah, semangat dan rasa senang dalam belajar, sehingga siswa yang mempunyai motivasi tinggi mempunyai energi yang banyak untuk melaksanakan kegiatan belajar.

Sebagaimana dikemukakan Sardiman (2009: 84) bahwa: Peran motivasi dalam belajar merupakan satu hal terpenting dalam kegiatan pembelajaran (Motivation is an essensial condition of learning). Hasil belajar akan menjadi optimal, jika ada motivasi. Makin tepat motivasi yang diberikan, akan makin berhasil pula pelajaran itu. Jadi motivasi akan senantiasa menentukan intensitas usaha belajar bagi para siswa. Motivasi sangat bertalian dengan tujuan. Dengan demikian, motivasi memengaruhi adanya kegiatan. Sehubungan dengan hal tersebut Sardiman (2009: 85) mengemukakan terdapat tiga peran motivasi lainnya : (1) Mendorong manusia untuk berbuat, jadi sebagai penggerak atau motor yang melepaskan energi. Motivasi dalam hal ini merupakan motor penggerak dari setiap kegiatan yang akan dikerjakan. (2) Menentukan arah perbuatan, yakni ke arah tujuan yang hendak dicapai. Dengan demikian motivasi dapat memberikan arah dan kegiatan yang harus dikerjakan sesuai dengan rumusan tujuannya. (3) Menyeleksi perbuatan, yakni menentukan perbuatan-perbuatan apa yang harus dikerjakan yang serasi guna mencapai tujuan, dengan menyisihkan perbuatan-perbuatan yang tidak bermanfaat bagi tujuan tersebut.

Berdasarkan pada peran motivasi belajar peserta didik dalam keberlangsungan pendidikan, maka motivasi belajar ini merupakan roda pendorong masa depan pendidikan. Peserta didik menjadi bagian yang akan turut serta mencerdaskan 
bangsa masa depan. Peserta didik yang berprestasi berawal dari motivasi belajar yang baik. Motivasi belajar yang terus di jaga dan ditingkatkan sampai tercapainya tujuan pembelajaran dan pendidikan nasional.

Penerapan Pembelajaran Saintifik Menggunakan Model ARCS dalam Perencanaan Pembelajaran

Dalam realitas, tidak sedikit guru yang bermasalah dalam pelaksanaan pembelajaran karena mereka seringkali kurang memiliki pengetahuan yang memadai tentang yang mereka ajarkan (Supardan, 2015: 165). Proses pelaksanaan pembelajaran merupakan kegiatan terencana yang disusun guru agar siswa mampu belajar dan mencapai kompetensi yang diharapkan. Jika guru akan melaksanakan pembelajaran, guru terlebih dahulu menyusun perencanaan pembelajaran. Cruickshanks (2009: 13) menyatakan bahwa "lesson plan describe specifically what and how something will be learned within a brief periode, usually one or a few class hours". Rencana pembelajaran menjelaskan secara spesifik apa dan bagaimana sesuatu akan dipelajari dalam periode singkat, biasanya satu atau beberapa jam pelajaran. Perencanaan pembelajaran tersebut nantinya akan digunakan sebagai panduan bagi guru dalam melaksanakan proses pembelajaran.

Jika kita lihat dari Permendikbud No. 103 tahun 2014 tentang Pembelajaran pada Pendidikan Dasar dan Pendidikan Menengah, Pedoman Pelaksanaan Pembelajaran, perencanaan pembelajaran dirancang dalam bentuk Silabus dan Rencana Pelaksanaan Pembelajaran (RPP) yang mengacu pada standar isi. Perencanaan pembelajaran meliputi penyusunan rencana pelaksanaan pembelajaran dan penyiapan media dan sumber belajar, perangkat penilaian pembelajaran, dan skenario pembelajaran. Penyusunan silabus dan RPP disesuaikan dengan pendekatan pembelajaran yang digunakan. Silabus dikembangkan berdasarkan Standar Kompetensi Lulusan (SKL) dan Standar Isi (SI) untuk satuan pendidikan dasar dan menengah sesuai dengan pola pembelajaran pada setiap tahun ajaran tertentu.

Dalam upaya meningkatkan motivasi belajar maka setiap guru dapat mengembangkan rancangan pembelajaran yang dibuatnya. Model yang diterapakan tentunya dipilih sebaik mungkin yang sesuai untuk meningkatkan motivasi belajar peserta didik. Selain menerapkan model pembelajaran guru dapat membuat instrumen sebagai alat ukur untuk melihat peningkatan motivasi belajar peserta didik setelah pembelajaran dilakukan. Model ARCS dapat diterapkan sebagai salah satu model yang digunakan dalam meningkatkan motivasi belajar peserta didik. Dalam model ARCS terdapat seperangkat soal berupa angket baku yang telah dirancang oleh Keller (1987: 6) yang dapat disesuaikan berdasarkan kriteria dan kondisi yaitu Instructional Materials Motivation Survey (IMMS). IMMS dirancang untuk mengukur motivasi belajar peserta didik terhadap suatu mata pelajaran yang dipelajari.

Guru dapat menggunakan seperangkat alat ukur IMMS sebagai upaya optimalisasi model ARCS yang diterapkan sehingga peningkatan motivasi belajar peserta didik dapat dipantau peningkatannya secara berkala dan dapat dipertahankan dalam kondisi motivasi belajar yang sangat baik. Sebelum dirancangnya Rencana Pelaksanaan Pembelajaran (RPP) menggunakan model ARCS dalam pembelajaran Saintifik terlebih dulu ditentukan metode yang akan digunakan. Mengacu pada model ARCS maka metode yang sebaiknya digunakan dalam pembelajaran adalah metode yang interaktif. Sebagai contoh penulis merancang RPP menggunakan metode diskusi. Berikut panduan langkah pembelajaran saintifik menggunakan model ARCS metode diskusi yang disusun berdasarkan sintaks pada masing-masing langkahnya.

Tabel 2. Langkah Langkah Pembelajaran Saintifik Model ARCS Metode Diskusi

\begin{tabular}{cl}
\hline No. & \multicolumn{1}{c}{ Langkah-Langkah Setiap Aspek } \\
\hline 1 & Pembelajaran Saintifik; \\
& $>$ Pendahuluan \\
& $>$ Mengamati \\
& $>$ Menanya \\
& $>$ Mengumpulkan Informasi \\
& $>$ Mengasosiasikan \\
& $>$ Mengkomunikasikan \\
& $>$ Penutup \\
\hline
\end{tabular}

16 http://ejournal.iainbengkulu.ac.id/index.php/ijisedu 


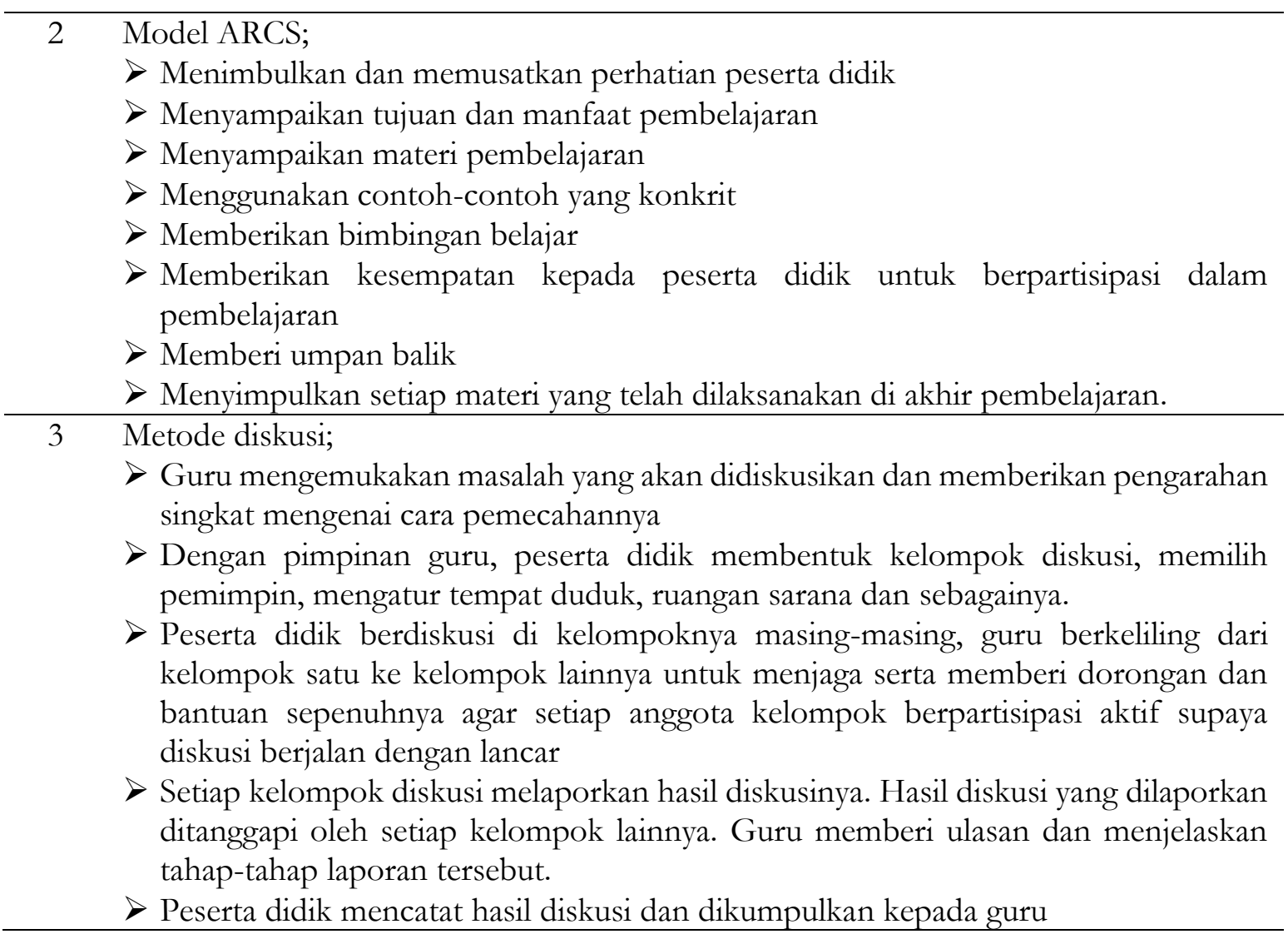

Dalam menyusun Rencana Pelaksanaan Pembelajaran penulis mengacu pada silabus yang berlaku. Setiap langkah dipadukan antara langkahlangkah pada pembelajaran saintifik, langkahlangkah pada model ARCS, dan langkah-langkah pada metode diskusi. Berikut adalah contoh penerapan model ARCS dalam pembelajaran saintifik menggunakan metode diskusi yang tersusun dalam Rencana Pelaksanaan Pembelajaran (RPP) yang dapat diterapkan di kelas Ilmu-Ilmu Sosial ataupun di kelas Matematika Ilmu Alam sebagai mata pelajaran peminatan

\section{Tabel 3. Contoh RPP Pembelajaran Saintifik Model ARCS Model Diskusi}

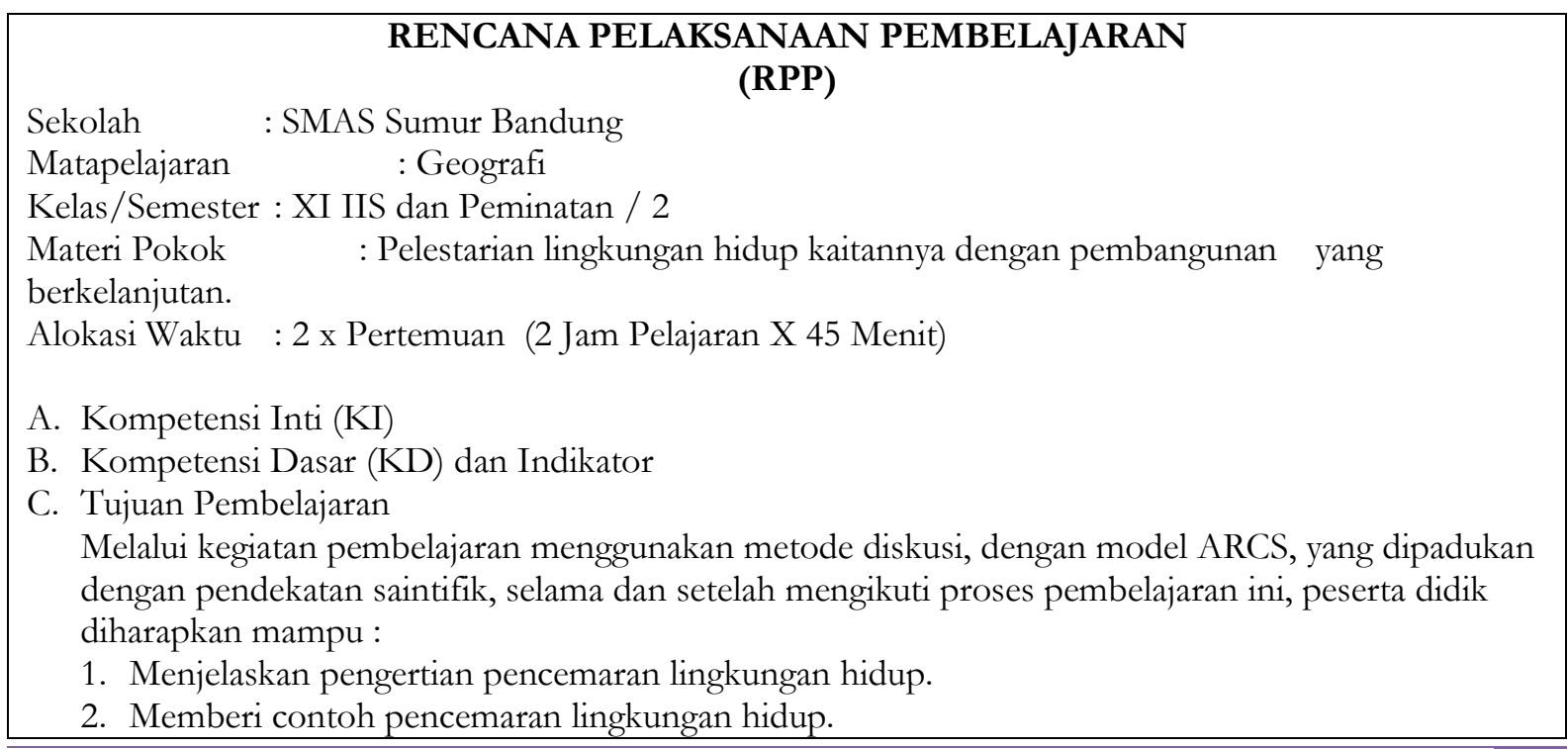


3. Menjelaskan 2-3 upaya mengatasi pencemaran lingkungan.

4. Menjelaskan pengertian pelestarian lingkungan hidup.

5. Memberi 2 contoh pelestarian lingkungan hidup.

6. Menjelaskan manfaat lingkungan hidup bagi pembangunan berkelanjutan.

7. Menyajikan laporan sederhana tentang lingkungan hidup dan pembangunan berkelanjutan

D. Materi Pembelajaran

1. Bentuk-bentuk pemanfaatan lingkungan, dan pencemaran lingkungan

2. Contoh tindakan-tindakan bijaksana yang tepat dalam pelestarian lingkungan hidup dan pembangunan berkelanjutan.

E. METODE PEMBELAJARAN
1. Pendekatan
: Scientific.
2. Model
: ARCS (Attention, Relevance, Confidence, Satisfaction).
3. Metode
: Diskusi

F. MEDIA, ALAT, DAN SUMBER PEMBELAJARAN

G. 1. LANGKAH-LANGKAH PEMBELAJARAN

\section{Pertemuan Ke-1}

Kegiatan Pendahuluan (20 menit)

Guru:

Orientasi (Menunujukkan sikap disiplin sebelum memulai proses pembelajaran, menghayati dan mengamalkan ajaran agama (Karakter) serta membiasakan membaca dan memaknai (Literasi)

* Melakukan pembukaan dengan salam pembuka dan berdoa untuk memulai pembelajaran

* Memeriksa kehadiran peserta didik sebagai sikap disiplin

* Menyiapkan fisik dan psikis peserta didik dalam mengawali kegiatan pembelajaran.

\section{Apersepsi}

* Mengaitkan materi / tema / kegiatan pembelajaran yang akan dilakukan dengan pengalaman peserta didik dengan materi / tema / kegiatan pembelajaran sebelumnya.

* Mengingatkan kembali dan mengajukan pertanyaan melalui soal-soal yang diajukan kepada peserta didik yang ada keterkaitannya dengan pelajaran yang akan dilakukan (tanya jawab mengulang kembali garis besar materi "Lingkungan Hidup dan Pengertian Pembangunan Berkelanjutan" yang telah dipelajari, mengaitkan dengan materi pelajaran "Bentuk Pemanfaatan dan Pencemaran Lingkungan" yang akan di sajikan)

\section{Motivasi}

* Memberikan gambaran tentang manfaat mempelajari "Bentuk Pemanfaatan dan Pencemaran Lingkungan" yang akan dipelajari

* Apabila materi/tema/projek ini dikerjakan dengan sungguh-sungguh dan dikuasai dengan baik, maka peserta didik diharapkan dapat menjelaskan tentang:

- Pemanfaatan lingkungan

- Pencemaran lingkungan

- Pelestarian lingkungan hidup

- Lingkungan hidup dalam pembangunan berkelanjutan

* Menyampaikan tujuan pembelajaran pada pertemuan yang sedang berlangsung

\section{Pemberian Acuan}

* Memberitahukan materi pelajaran yang akan dibahas pada pertemuan saat itu

\section{Model ARCS}

1) Menimbulkan dan memusatkan perhatian peserta didik (Attention) Ket:

- Guru menarik perhatian peserta didik dengan cara mengulang kembali pelajaran atau materi yang telah dipelajari peserta didik dan mengaitkan materi tersebut dengan materi yang akan disajikan. Dengan menggunakan tanya jawab dan memberikan penguatan pada jawaban yang tepat.

- Guru bercerita tentang pentingnya materi yang akan dipelajari. Dengan cara ini peserta didik akan merasa tertarik serta termotivasi untuk memperoleh 


\begin{tabular}{|c|c|}
\hline $\begin{array}{l}\text { Memberitahukan tentang kompetensi inti, kompetensi dasar, indikator, } \\
\text { KKM pada pertemuan yang berlangsung } \\
\text { Pembagian kelompok belajar dan menjelaskan mekanisme pelaksanaan } \\
\text { pengalaman belajar sesuai dengan langkah-langkah pembelajaran. }\end{array}$ & $\begin{array}{l}\text { pengetahuan } \\
\text { yang baru yaitu } \\
\text { materi pelajaran } \\
\text { yang akan } \\
\text { disajikan } \\
\text { 2)Menyampaikan tujuan } \\
\text { dan manfaat } \\
\text { pembelajaran (R) } \\
\text { Ket: } \quad \\
\text { Guru } \\
\text { mendeskrispsik } \\
\text { an tujuan dan } \\
\text { manfaat } \\
\text { pembelajaran, } \\
\text { serta dapat } \\
\text { mengetahui } \\
\text { hubungan atau } \\
\text { keterkaitan } \\
\text { antara materi } \\
\text { pembelajaran } \\
\text { yang disajikan } \\
\text { dengan } \\
\text { pengalaman } \\
\text { belajar peserta } \\
\text { didik }\end{array}$ \\
\hline Kegiatan Inti (50 menit) & \multirow{2}{*}{$\begin{array}{l}\text { 3)Menyampaikan materi } \\
\text { pelajaran }(\mathrm{R})\end{array}$} \\
\hline Kegiatan Pembelajaran & \\
\hline $\begin{array}{l}\text { Mengamati } \\
\text { Menggali permasalahan tentang "Bentuk-bentuk pemanfaatan } \\
\text { lingkungan, pencemaran lingkungan, pelestarian lingkungan hidup, } \\
\text { dan lingkungan hidup dalam pembangunan berkelanjutan" } \\
\text { Peserta didik mengamati guru yang menunjukkan gambar dan video } \\
\text { tentang permasalahan lingkungan yang berkaitan dengan bentuk } \\
\text { pencemaran, pemanfaatan, dan pelestarian lingkungan hidup dalam } \\
\text { pembangunan berkelanjutan. } \\
\text { Menanya } \\
\text { Peserta didik merumuskan masalah yang telah dibagikan di dalam } \\
\text { amplop sesuai kelompoknya masing-masing } \\
\text { Kelompok 1: Selama beberapa tahun belakangan ini, setidaknya } 64 \\
\text { dari } 470 \text { daerah aliran sungai mengalami kondisi yang kritis, hal ini } \\
\text { disebabkan beberapa hal seperti limbah industri yang terkandung } \\
\text { berbagai zat kimia di dalamnya, limbah domestik seperti limbah } \\
\text { rumah tangga yang sengaja di buang ke sungai, limbah pertanian dan } \\
\text { masih banyak lainnya. Sebagai salah satu contoh, di daerah sekitar kita } \\
\text { terdapat suatu tempat yang saat ini dijadikan objek wisata yaitu Napak } \\
\text { Sancang Floating Resto yang berada di tengah sungai Citarum sebagai } \\
\text { salah satu wujud pemanfaatan lingkungan sekitar, sejak tempat ini } \\
\text { didirikan masyarakat semakin mengenal sungai Citarum yang } \\
\text { berhubungan langsung dengan waduk Saguling ini. Pengunjung yang } \\
\text { datang pun tentunya beragam mulai dari masyarakat setempat bahkan } \\
\text { tak jarang turis asing. Selain sebagai salah satu wisata kuliner tempat } \\
\text { ini juga memiliki pemandangan yang indah bagi wisatawan, sebab } \\
\text { tidak hanya sungai namun perbukitan Bandung Barat pun menjadi }\end{array}$ & $\begin{array}{ll}\text { Ket: } & \\
\text { - } & \text { Guru } \\
& \text { menyampaikan } \\
& \text { materi } \\
& \text { pembelajaran } \\
& \text { dan penugasan } \\
& \text { secara jelas dan } \\
& \text { terperinci. } \\
& \text { Kajian materi } \\
\text { pembelajaran } \\
\text { ini dilakukan } \\
\text { dengan cara } \\
\text { yang menarik } \\
\text { sehingga dapat } \\
\text { menumbuhkan } \\
\text { atau menjaga } \\
\text { perhatian } \\
\text { peserta didik. } \\
\text { Pembahasan } \\
\text { materi dapat } \\
\text { disampaikan } \\
\text { melalui proses } \\
\text { interaktif. }\end{array}$ \\
\hline
\end{tabular}




\begin{tabular}{|c|c|}
\hline $\begin{array}{l}\text { salah satu daya tarik nya. Akan tetapi tempat ini ternyata melupakan } \\
\text { sarana umum seperti toilet dan tempat sampah khusus di area } \\
\text { tersebut, sehingga tak jarang sampah organik dan anorganik pun } \\
\text { mencemari kebersihan sungai ini dan merusak pandangan nyaman } \\
\text { wisatawan. Diskusikan dan Buatlah kesimpulan dalam bentuk } \\
\text { laporan bagaimana upaya yang harus dilakukan pada permasalahan } \\
\text { tersebut! } \\
\text { Mengumpulkan informasi } \\
\text { Setiap kelompok membaca, mengkaji, dan berdiskusi sesuai tema } \\
\text { kelompok berdasarkan sumber bacaan masing-masing } \\
\text { Mengasosiasikan } \\
\text { *elompok } 1 \text { menyajikan hasil pekerjaannya melalui presentasi dan } \\
\text { memberikan contoh-contoh yang berhubungan dengan kehidupan } \\
\text { sehari-hari peserta didik. } \\
\text { Memotivasi dan mengarahkan peserta didik menyimak kelompok } \\
\text { penyaji yang maju presentasi agar dapat mudah memahami materi } \\
\text { pembelajaran. } \\
\text { Mengarahkan peserta didik melalui kelompoknya masing-masing } \\
\text { mengajukan pertanyaan tentang tema yang berkaitan dari kelompok } \\
\text { yang presentasi. } \\
\text { Peserta didik diminta untuk menanggapi atau menjawab pertanyaan- } \\
\text { pertanyaan tentang tema yang berkaitan dari kelompok yang presentasi } \\
\text { yaitu mengenai pemanfaatan dan pencemaran lingkungan. } \\
\text { * Peserta didik menjawab pertanyaan yang diajukan kelompok lain } \\
\text { tentang pemanfaatan lingkungan dan pencemaran lingkungan. } \\
\text { Mendampingi dan menguatkan rasa percaya diri peserta didik saat } \\
\text { menyampaikan argumentasi dari pertanyaan kelompok lain tentang } \\
\text { pembahasan tema yang disajikannya. } \\
\text { * Peseta didik membuat ringkasan dari sajian presentasi kelompoknya. } \\
\text { Bertanya tentang hal yang belum dipahami atau guru melemparkan } \\
\text { beberapa pertanyaan kepada peserta didik. }\end{array}$ & 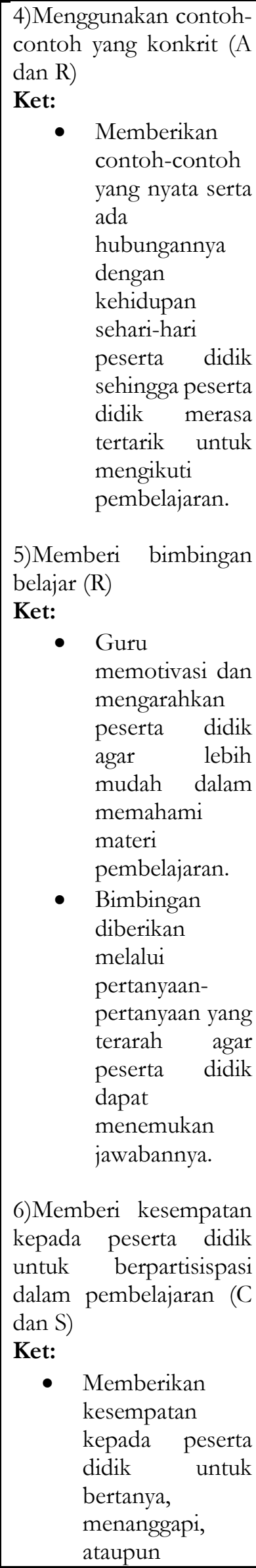 \\
\hline
\end{tabular}




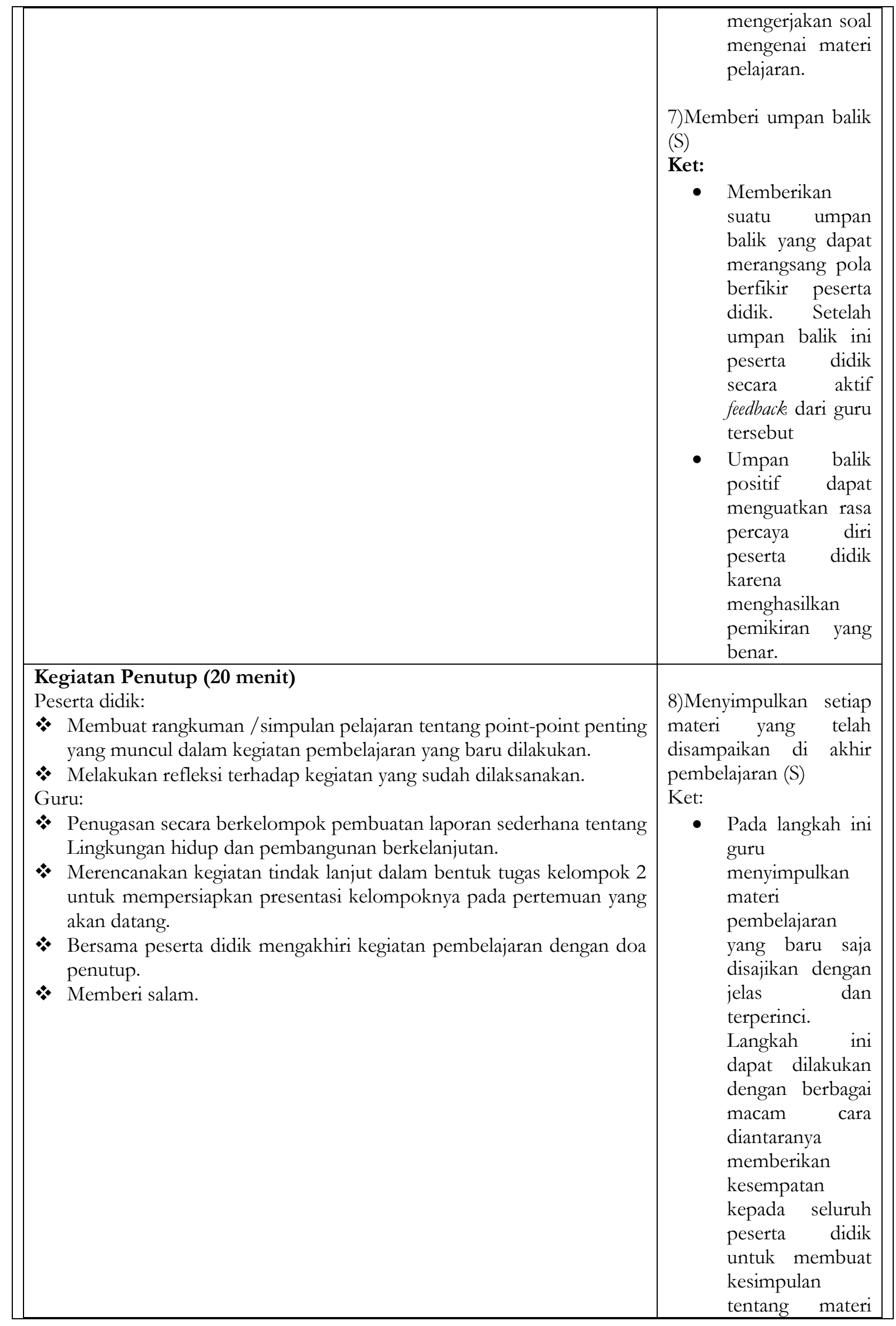




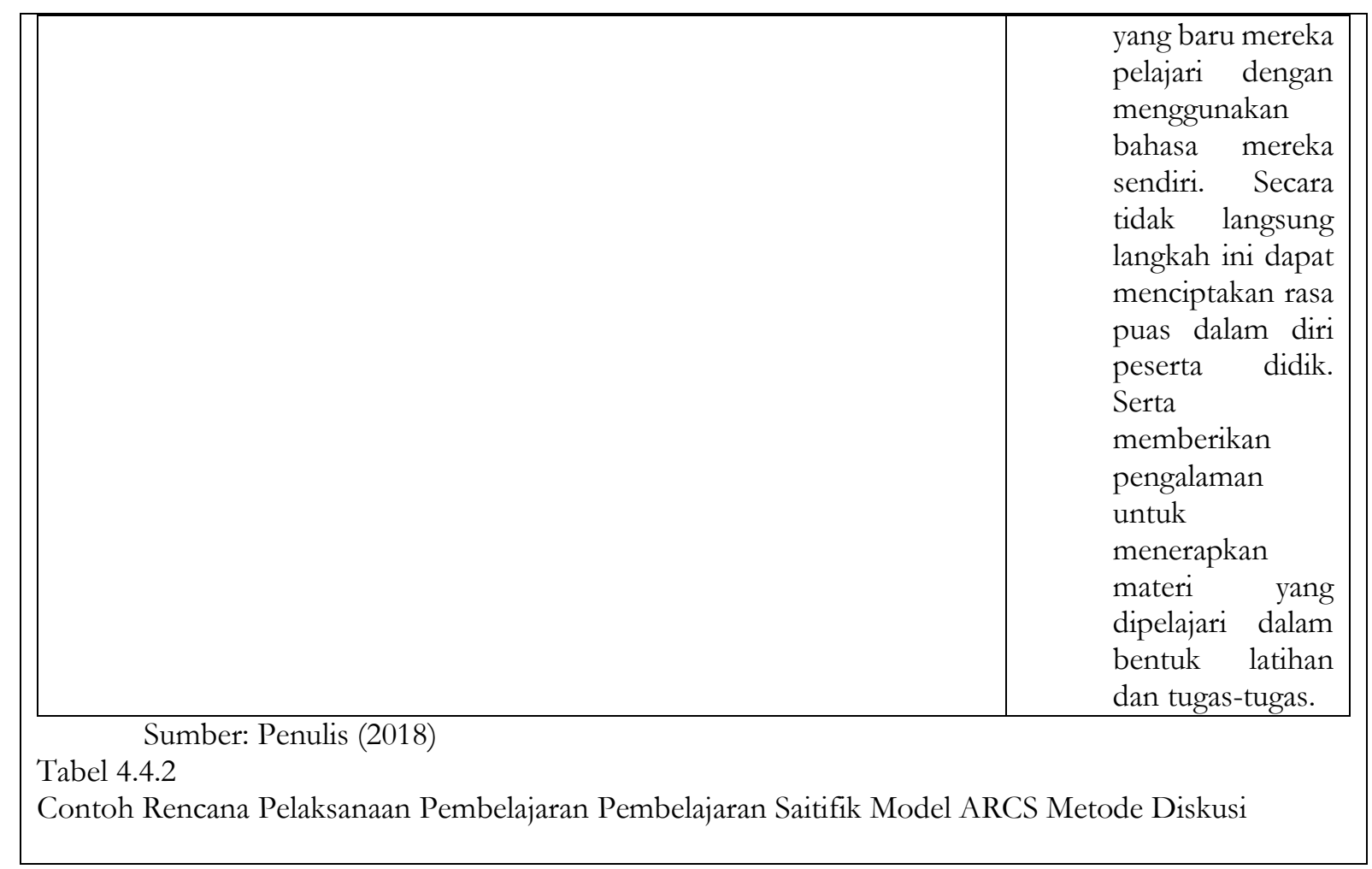

\section{SIMPULAN}

Motivasi belajar menjadi sebuah penggerak semangat dan minat dalam mempertahankan dan meningkatkan prestasi belajar untuk ketercapaian tujuan pendidikan. Guru dalam hal ini berperan aktif untuk mengelola kelas dengan cara yang kreatif dalam menumbuhkan motivasi belajar peserta didik melalui berbagai metode dan model yang digunakan. Model ARCS dapat menjadi salah satu alternatif untuk mempertahankan dan menumbuhkan motivasi belajar peserta didik baik digunakan sebagai model pembelajaran dan alat ukur tingkat motivasi belajar peserta didik.

Mempertahankan dan meningkatkan motivasi belajar peserta didik menjadi hal yang sangat penting untuk menjadikan peserta didik sebagai generasi penerus bangsa yang cerdas komprehensif dan kompetitif. Keberhasilan pembelajaran saintifik dapat didukung dengan penggunaan model dan metode pembelajaran yang tepat. Optimalisasi model ARCS dapat diterapkan dengan langkah-langkah dan pelaksanaan yang benar sesuai sintaks dan dipadukan dengan kurikulum yang sedang berjalan dalam hal ini pembelajaran saintifik. Sesuai kurikulum yang berlaku mata pelajaran Geografi menjadi salah satu mata pelajaran peminatan yang dapat diikuti peserta didik dari kelas Matematika Ilmu Alam. 


\section{DAFTAR PUSTAKA}

Ababio, B. T. (2013). Motivation and Classroom Teaching in Geography. International Journal For Innovation Education and Research. Vol. 1, No. 3, 2013

Cruickshank D.R., Jenkins D.B., \& Metcalf K.K. (2009). The act of teaching. 5th edition. Boston: McGraw Hill.

Fitri, Aliningsih Ahmad Sofyan (2015) English Teacher Perseptions and Practices of Authentik Assessment. Journal Lof Language and Literature.

Gagne, R. (1974). The Condition Of Learning. New York: Holt, Rinehart \& Winston.

Keller, J. M. (1983). Motivational design of instruction. In C.M Reigeluth (Ed), Instructional-design theories and models: $A n$ overview of their current status. Hillsdale, NJ: Lawrence Earlbaum Associates.

(1987). Development and use of the ARCS model of motivational design. Journal of Instructional Development, 10(3), 2-10.

(2006). Development of two Measure of learner Motivation. Draft In Progress, version 060222.

Keller, J. M., \& Kopp, T. W. (1987). Application of the ARCS model of motivational design. In C. M. Reigeluth (Ed.), Instructional theories in action: Lessons illustrating selected theories and models. Hillsdale, NJ: Lawrence Earlbaum Associates.

Kosasih. (2014) Strategi Belajar dan Pembelajaran. Bandung: Yrama Widya

Kurniasih, Imas \& Sani, Berlin. (2014). Implementasi Kurikulum 2013 Konsep \& Penerapan. Surabaya: Kata Pena.

Lie, A (2003). Cooperatif Learning: Mempraktekkan Cooperatif Learning di Ruang-Ruang Kelas. Jakarta: Gramedia.

Liu, Meihua. (2007). Chinese Students Motivation to Learn English at the Tertiary Level: Asian Journal of Distance Education. Vol 9.
Machin, A. (2014). Implementasi Pendekatan Saintifik, Penanaman Karakter dan Konservasi pada Pembelajaran Materi Pertumbuban. Vol 3 No 1

McCombs, B. L. (1984). Processes and skills underlying continuing intrinsic motivation to learn: Toward a definition of motivational skills training. Educational Psychologist, 4, 190-218.

Muhajir \& Khatimah., Y.R. (2013). Buku pendoman pengembangan dan implementasi kurikulum 2013. Jakarta: Kemendikbud RI Unit Implementasi Kurikulum 2013.

Qismina, Q. (2009). Gambaran Motivasi Belajar Mahasiswi Prodi Kebidanan Cipto Mangunkusumo Semester III Umum Pada Mata Kuliah Farmakologi Tabun 2009. Karya Tulis Ilmiah pada POLTEKES DEPKES JAKARTA III: Tidak diterbitkan.

Roestiyah. (2012). Strategi Belajar Mengajar. Jakarta: Rineka Cipta

Rusman. (2010). Model-Model Pembelajaran. Jakarta: Raja Grafindo Persada.

Rusyan, Tabrani. (1989). Pendekatan Dalam Proses Belajar Mengajar, Bandung: CV. Remaja Rosda Karya.

Sardiman, A.M. (2009) 'Interaksi\&Motivasi Belajar Mengajar", Jakarta: Rajawali Pers.

Savage \& Armstrong. (1996). Effective Teaching in Elementary Social Studies. America: Prentice-Hall, Inc.

Schmitt, M. C., \& Newby, T. J. (1986). Metacognition: Relevance to Instructional design. Journal of Instructional Development, 9(4), 29-33.

Semiawan, Conny. (1991) "Mencari Strategi Pengembangan Pendidikan Nasional Menjelang Abad 21", Jakarta, PT. Gramedia.

Slavin, R. E. (1991). Educational Psychology: Theory into Practice $3^{\text {rd }}$. Johns Hopkins University: Allyn and Bacon 
Sudjana, Dj. (2000). Strategi Pembelajaran. Bandung; Falah Production.

Supardan, Dadang. (2015). Pembelajaran Ilmu Pengetahuan Sosial, Persfektif Filosofi dan Kurikulum. Bandung. Bumi Aksara

Suriasumantri, Jujun S. (2009) Filsafat Ilmu Sebuah Pengantar Populer, Jakarta: Pustaka Sinar Harapan.

Tim Penyusun Kamus Pusat Pembinaan dan Pengembangan Bahasa (2008), Kamus
Besar Bahasa Indonesia, Jakarta: Balai Pustak

Yani, A dan Ruhimat, M (2018). Teori dan Implementasi Pembelajaran Saintifik Kurikulum 2013, Bandung: PT Refika Aditama

Zamroni. (2002). Paradigma Pendidikan Masa Depan. Yogyakarta: Biografi Publishing 